\title{
PHOTOSTABILITY STUDY OF AMLODIPINE BESYLATE TABLETS PACKED IN PRIMARY PACKAGING
}

Ivana M. Savic Gajićc ${ }^{*}$, Ivan M. Savić ${ }^{1}$, Predrag S. Sibinović ${ }^{2}$, Valentina D. Marinković ${ }^{3}$

(ORIGINAL SCIENTIFIC PAPER)

UDC 615.22:544.14:543.54

DOI 10.5937/savteh2101020S

${ }^{1}$ Faculty of Technology in Leskovac, University of Niš, Bulevar oslobođenja 124, 16000 Leskovac, Serbia,
${ }^{2}$ Pharmaceutical and Chemical Industry - Zdravlje Actavis, Vlajkova 199, 16000 Leskovac, Serbia,

${ }^{3}$ Faculty of Pharmacy, University of Belgrade, Vojvode Stepe 450, 11221 Belgrade, Serbia.

In this study, the modified stability-indicating RP-HPLC method was validated for quantitative analysis of amlodipine besylate in the presence of its impurity $D$ (3-ethyl 5-methyl 2-[(2-aminoethoxy)methyl]-4-(2-chlorophenyl)-6-methylpyridine-3,5-dicarboxylate). The method was applied for the determination of an analyte in the tablets and irradiated samples packed in the primary packaging (Alu/PVC/PVDC blister packaging). The efficient chromatographic separation was achieved using a ZORBAX Eclipse XDB-C18 column $(4.6 \times 250 \mathrm{~mm}, 5 \mu \mathrm{m})$ with isocratic elution of mobile phase which consisted of acetonitrile:methanol:triethylamine solution (15:35:50, v/v/v) $(\mathrm{pH} 3.0)$. The flow rate of the mobile phase was $1 \mathrm{~mL} \mathrm{~min}^{-1}$, while the detection of amlodipine besylate was carried out at $273 \mathrm{~nm}$. Amlodipine besylate and its impurity D were identified at the retention times of 16.529 min and $2.575 \mathrm{~min}$, respectively. The linearity of the method with the coefficient of determination of 0.999 was confirmed in the concentration range of $10-75 \mu \mathrm{g} \mathrm{mL}^{-1}$ for amlodipine besylate. The limit of detection was $0.2 \mu \mathrm{g} \mathrm{mL}^{-1}$, while the limit of quantification was $0.66 \mathrm{\mu g} \mathrm{mL}^{-1}$. After UV and Vis radiation of the tablets packed in the primary packaging, the content of amlodipine besylate was reduced by $22.38 \%$ and $19.89 \%$, respectively. The presence of new degradation products was not detected under the given chromatographic conditions. The photodegradation of amlodipine besylate followed pseudo-first-order kinetics. Based on the half-life of amlodipine besylate (38.4 days for UV radiation and 43.3 days for Vis radiation), it was concluded that amlodipine besylate in the tablets has satisfactory photostability after its packing in the Alu/PVC/PVDC blister packaging.
Keywords: drug, photodegradation, kinetics, RP-HPLC, primary packaging

\section{Introduction}

Stress studies are an important part of the drug development process. They are carried out to examine the chemical stability and define the degradation pathways of the drug substance, define their stability in the pharmaceutical products, as well as identify potential degradation products [1]. Useful information from the aspect of drug design, choice of packaging material, and drug storage conditions can be obtained in this study. The experimental conditions of stress studies according to the guidelines of the International Conference on Harmonization $(\mathrm{ICH})$ should include testing for susceptibility of the drug to hydrolysis, oxidation, thermal degradation, and moisture. Photostability as an integral part of stress studies is described in detail in the ICH Q1B guideline [2].

Amlodipine besylate is a derivative of 1,4-dihydropyridine that has aromatic nitro, carbonyl, alkene, and aryl halide groups, which are responsible for its photoreactivity [3]. It belongs to a class of dihydropyridines commonly referred to as calcium channel blockers or calcium antagonists [4]. They reduce the movement of calcium into the cell and delay or prevent cardiac contracture, which is caused by an accumulation of intracellular calcium under ischemic conditions. The excessive calcium influx during ischemia can have several additional adverse effects that would further compromise the ischemic myocardium. These include less efficient use of oxygen to produce ATP, activation of mitochondrial oxidation of fatty acids, and promotion of cell necrosis. Therefore, calcium antagonists are useful in the treatment or prevention of various cardiac conditions, such as angina pectoris, cardiac arrhythmias, heart attacks, and cardiac hypertrophy [5]. Calcium antagonists also have vasodilator activity because they can inhibit calcium influx in cells of vascular tissue and can be useful as antihypertensive agents.

Amlodipine besylate is official in the European Pharmacopoeia 7.0 (Ph. Eur. 7.0) that prescribed the RPHPLC method with isocratic elution and using $C_{18}$ column for determination of this active substance and its related substances (impurities) [6]. The various stability-indicating methods (Tables $1-3$ ) were developed and validat-

\footnotetext{
*Author address: Ivana M. Savić Gajić, Faculty of Technology in Leskovac, University of Niš,

Bulevar oslobođenja 124, 16000 Leskovac, Serbia

e-mail: savicivana@tf.ni.ac.rs

The manuscript received: April, 23, 2021.

Paper accepted: Jun, 09, 2021.
} 
ed for the determination of amlodipine besylate content in the bulk and pharmaceutical formulations (alone or in combination with other cardiovascular drugs) after exposure to various stress conditions (acid and base hydrolysis, oxidation, photodegradation).

Table 1. A review of spectroscopic methods for determination of amlodipine besylate

\begin{tabular}{|c|c|c|c|c|}
\hline Method & $\begin{array}{l}\text { Detection } \\
(\mathrm{nm})\end{array}$ & Sample & $\begin{array}{c}\text { Linearity, LOD/LOQ } \\
\left(\mu \mathrm{g} \mathrm{mL}^{-1}\right)\end{array}$ & Reference \\
\hline $\begin{array}{l}\text { Derivative UV method } \\
\text { with benzoyl chloride }\end{array}$ & 237 & $\begin{array}{l}\text { The aqueous solution of } \\
\text { amlodipine besylate }\end{array}$ & $1-10,0.24 / 0.72$ & [7] \\
\hline $\begin{array}{l}\text { Derivative UV method } \\
\text { with sodium 1,2- } \\
\text { naphthoquinone-4- } \\
\text { sulfonate }\end{array}$ & 459 & $\begin{array}{c}\text { Ethanolic solution of } \\
\text { amlodipine besylate } \\
\text { tablets }\end{array}$ & $10-20,1.12 / 3.36$ & [8] \\
\hline
\end{tabular}

Table 2. A review of chromatographic methods for determination of amlodipine besylate

\begin{tabular}{|c|c|c|c|c|c|}
\hline $\begin{array}{c}\text { Stationary } \\
\text { phase }\end{array}$ & Mobile phase & $\begin{array}{l}\text { Detection } \\
\text { (nm) }\end{array}$ & Sample & $\begin{array}{c}\text { Linearity, } \\
\text { LOD/LOQ ( } \mu \mathrm{g} \\
\left.\mathrm{mL}^{-1}\right)\end{array}$ & Reference \\
\hline ODS1 & $\begin{array}{l}2.3 \mathrm{~g} \mathrm{~L}^{-1} \text { ammonium } \\
\text { acetate:methanol } \\
(30: 70, \mathrm{v} / \mathrm{v})\end{array}$ & 237 & $\begin{array}{l}\text { The solution of } \\
\text { amlodipine }\end{array}$ & - & [9] \\
\hline $\begin{array}{l}\text { UPLC CSH } \\
\mathrm{C}_{18}(150 \times 3.0 \\
\mathrm{mm}, 1.7 \mu \mathrm{m})\end{array}$ & $\begin{array}{l}0.1 \% \text { formic acid }(A) \\
\text { and acetonitrile }(B) \text {, } \\
\text { gradient elution }\end{array}$ & 360 & $\begin{array}{l}\text { Multicomponent } \\
\text { tablets }\end{array}$ & - & [10] \\
\hline $\begin{array}{l}\mathrm{SB}-\mathrm{C}_{8}(4.6 \times \\
250 \mathrm{~mm}, 5 \\
\mu \mathrm{m})\end{array}$ & $\begin{array}{l}0.025 \mathrm{M} \text { phosphoric } \\
\text { acid and acetonitrile, } \\
\text { gradient elution }\end{array}$ & 238 & $\begin{array}{c}\text { Tabets of } \\
\text { amlodipine } \\
\text { besylate, valsartan } \\
\text { and } \\
\text { hydrochlorothiazide }\end{array}$ & $\begin{array}{c}5-200 \\
0.26 / 0.85\end{array}$ & [11] \\
\hline $\begin{array}{l}\text { UPLC BEH } \\
\text { C18 (50 mm } \\
\times 2.1 \mathrm{~mm} \\
1.7 \mu \mathrm{m})\end{array}$ & $\begin{array}{l}20 \mathrm{mM} \text { potassium } \\
\text { phosphate buffer } \mathrm{pH} \\
3 \text { (adjusted by } \\
\text { orthophosphoric } \\
\text { acid):methanol } \\
(55: 45, \mathrm{v} / \mathrm{v} \text { ) with the } \\
\text { addition of TEA }\end{array}$ & 237 & $\begin{array}{l}\text { Tablets of } \\
\text { amlodipine } \\
\text { besylate and } \\
\text { olmesartan } \\
\text { medoxomil }\end{array}$ & $\begin{array}{c}25-75 \\
0.58 / 1.75\end{array}$ & [12] \\
\hline
\end{tabular}

Table 3. Thin-layer chromatographic methods for determination of amlodipine besylate

\begin{tabular}{|c|c|c|c|c|c|}
\hline $\begin{array}{l}\text { Stationary } \\
\text { phase }\end{array}$ & Mobile phase & Detection & Sample & $\begin{array}{l}\text { Linearity, } \\
\text { LOD/LOQ }\end{array}$ & Reference \\
\hline $\begin{array}{l}\text { Silica gel } \\
60 F_{254}\end{array}$ & $\begin{array}{l}\text { chloroform:methanol: } \\
\text { formic acid } \\
(8: 2.5: 0.5, v / v / v)\end{array}$ & $\begin{array}{l}\text { Densitometric, } \\
251 \mathrm{~nm}\end{array}$ & $\begin{array}{l}\text { Tablets of amlodipine } \\
\text { besylate and } \\
\text { telmisartan }\end{array}$ & $\begin{array}{c}100-600 \mu g \\
\mathrm{~mL}^{-1} \\
\text { n.r. }\end{array}$ & [13] \\
\hline $\begin{array}{l}\text { Silica gel } \\
60 F_{254}\end{array}$ & $\begin{array}{l}\text { chloroform:butane-1- } \\
\text { ol:ammonia } \\
(6: 4: 0.1, \mathrm{v} / \mathrm{v} / \mathrm{v})\end{array}$ & $\begin{array}{l}\text { Densitometric, } \\
254 \mathrm{~nm}\end{array}$ & $\begin{array}{l}\text { Methanolic solution } \\
\text { of tablets of } \\
\text { amlodipine besylate, } \\
\text { hydrochlorothiazide, } \\
\text { and telmisartan }\end{array}$ & $\begin{array}{l}200-1000 \mathrm{ng} \\
\text { spot }^{-1}, 8.6 \mathrm{ng} \\
\text { spot }^{-1} \\
26.1 \mathrm{ng} \mathrm{spot}^{-1}\end{array}$ & [14] \\
\hline
\end{tabular}

n.r. - not reported 
Comparing the methods developed for the determination of amlodipine besylate content, it can be noticed that spectroscopic methods require prior sample derivatization. The HPTLC method is less sensitive and the separation efficiency of amlodipine from degradation products is lower compared to the HPLC method. Because of that, the HPLC is the preferred method for monitoring the content of amlodipine besylate and its degradation products formed during the stability study.

The effect of primary packaging on the photostability of amlodipine besylate tablets has not been sufficiently studied in the literature. The use of the RP-HPLC method to monitor the degradation of amlodipine besylate in the presence of its impurity $D$ (3-ethyl 5-methyl 2-[(2-aminoethoxy)methyl]-4-(2-chlorophenyl)-6-methylpyridine-3,5-dicarboxylate) under stress conditions has also not been reported. The aim of this study was to develop and validate the modified stability-indicating RP-HPLC method for quantitative and qualitative analysis of amlodipine besylate in the presence of its impurity $D$ in the formulation and the samples obtained after photodegradation. The kinetics of photodegradation was studied to define the half-life of the product packed into the Alu/ PVC/PVDC blister packaging. In this way, it is possible to understand the effect of primary packaging on the photostability of this active substance.

\section{Material and methods}

\section{Chemicals and reagents}

Amlodipine besylate (Nosch Labs, Hyderabad, India), the impurity $\mathrm{D}$ of amlodipine besylate (3-ethyl 5-methyl 2-[(2-aminoethoxy)methyl]-4-(2-chlorophenyl)-6-methylpyridine-3,5-dicarboxylate), methanol (HPLC grade), acetonitrile (HPLC grade), phosphoric acid (HPLC grade), water (HPLC grade) (Merck, Darmstadt, Germany), and triethylamine (Qualigens Fine Chemicals, Delhi, India) were used in this study.

\section{Pharmaceutical product}

The tablets containing $10 \mathrm{mg}$ of amlodipine besylate were purchased at the local pharmacy. The product excipients were: microcrystalline cellulose, corn starch, colloidal silicon dioxide, povidone $\mathrm{K} 30$, and magnesium stearate.

\section{Apparatus}

The separation was carried out using an Agilent 1100-Series HPLC system (Agilent Technologies, Santa Clara, CA, USA) equipped with the HP G13141A variable wavelength UV detector and Agilent 1100-Series autosampler. The system was controlled and data analyses were performed by Agilent HPLC Data Analysis software. The reproducibility was performed by another LC system (Agilent Technologies, Santa Clara, CA, USA) equipped with the Agilent 1100-Series binary pump and Agilent 1100-Series DAD detector. The peak areas were integrated automatically using the Agilent HPLC Data Analy- sis software program.

\section{Chromatographic conditions}

The RP-HPLC analysis was performed by isocratic elution with a flow rate of $1 \mathrm{~mL} \mathrm{~min}{ }^{-1}$. A mobile phase contained acetonitrile:methanol:triethylamine solution $(15: 35: 50, v / v / v)$. The triethylamine solution was prepared by dissolving $7.0 \mathrm{~mL}$ of triethylamine in $1 \mathrm{~L}$ of distilled water and adjusted to $\mathrm{pH} 3.0$ using a concentrated phosphoric acid. The solvents were filtered through a $0.45 \mu \mathrm{m}$ millipore filter (Econofilters, Agilent Technologies, Germany). The injection volume of the samples was $10 \mu \mathrm{L}$. The eluent was monitored at $237 \mathrm{~nm}$. The separation of amlodipine besylate from its impurity $D$ was carried out at $20^{\circ} \mathrm{C}$ using a ZORBAX Eclipse XDB$\mathrm{C}_{18}$ column $(4.6 \times 150 \mathrm{~mm}, 5 \mu \mathrm{m})$ (Agilent Technologies, Santa Clara, CA, USA).

\section{Preparation of standard solution}

The stock solution of amlodipine besylate was prepared by dissolving $50.0 \mathrm{mg}$ of this substance in $50 \mathrm{~mL}$ of the mobile phase. It was homogenized using an ultrasonic bath for $15 \mathrm{~min}$. The solution of impurity $\mathrm{D}\left(10 \mu \mathrm{g} \mathrm{mL} \mathrm{m}^{-1}\right)$ was also prepared in the mobile phase.

\section{Validation study}

The validation is a key phase in the development of analytical methods for routine drug analysis because it is important to ensure product quality. The development and validation of modified stability-indicating RP-HPLC method for quantitative analysis of amlodipine besylate in the presence of its impurity $D$ in the tablets and samples obtained after photodegradation was carried out according to the ICH Q2(R1) guidelines [15].

Selectivity. The method selectivity was confirmed by scanning the mixture of amlodipine besylate and its impurity $D$, as well as the placebo sample (only tablet excipients).

Linearity. A series of standard solutions of amlodipine besylate in the concentration range of $1-100 \mu \mathrm{gL}^{-1}$ was prepared to define the method linearity. The leastsquare method was used to determine the parameters of linear dependency between peak area and concentration of amlodipine besylate.

Accuracy. The three standard solutions of amlodipine besylate $\left(10,20\right.$, and $\left.30 \mu \mathrm{g} \mathrm{mL}^{-1}\right)$ were used for the determination of the accuracy of the method. The measurement was repeated ten times $(n=10)$. The method's accuracy was estimated based on the recovery (theoretical value of $100 \%$ ).

Precision. The precision of the method was defined through the three levels: repeatability, mean precision, and reproducibility. The solutions of amlodipine besylate $\left(10,20\right.$, and $\left.30 \mu \mathrm{g} \mathrm{mL}^{-1}\right)$ were also used for the evaluation of repeatability and mean precision. The reproducibility of the method was also analyzed of these solutions on the other LC system (Agilent 1100-Series system). The method is adequate precision if the RSD values are 
lower than $1 \%$ for repeatability and mean precision, i.e. lower than $3 \%$ for reproducibility.

Limit of detection and limit of quantification. The limit of detection $(L O D)$ and limit of quantification ( $L O Q)$ were determined using the data of the calibration curve according to Equations 1 and 2 [16]:

$L O D=3.3 \frac{S_{0}}{b}$

$L O Q=10 \frac{S_{0}}{b}$

where are, $S_{0}$ - standard deviation of the intercept and $b-$ the slope.

Robustness. The robustness of the method was estimated based on the change in the number of theoretical plates and peak asymmetry due to the change in the flow rate of the mobile phase and the ratio of acetonitrile in the mobile phase. The flow rate of the mobile phase was changed for 0.2 units in the range of $0.8-1.2 \mathrm{~mL} \mathrm{~min}^{-1}$, while the composition of the mobile phase was unchanged. The ratio of acetonitrile was varied in the range of $10-20 \%(\mathrm{v} / \mathrm{v})$.

Preparation of tablets for assay

Ten tablets were weighed, crushed, and mixed in a mortar and pestle for $20 \mathrm{~min}$. The portion of powder equivalent to the weight of one tablet was accurately weighed into a $100 \mathrm{~mL}$ volumetric flask and $50 \mathrm{~mL}$ of mobile phase was added. The sample was sonicated for $30 \mathrm{~min}$ to complete dissolution of amlodipine besylate, and then the mobile phase was filled to the mark. The obtained solution was filtered through a membrane filter of $0.45 \mu \mathrm{m}$. The concentration of the prepared solution was $50 \mu \mathrm{g} \mathrm{mL}^{-1}$.

Photostability studies

The tablets were packed in the Alu/PVC (polyvinyl chloride)/PVDC (polyvinylidene chloride) blister packaging and exposed to the effect of light to investigate drug photostability. All samples were placed in a light cabinet (Suntest CPS/CPS+, Atlas Material Testing Technology, Germany) and exposed to different wavelengths (254 nm and $540 \mathrm{~nm}$ ) for 14 days. The content of amlodipine besylate and its impurity $D$ was monitored by the validated stability-indicating RP-HPLC method that should enable efficient separation and quantification of any degradation products.

\section{Data analysis}

The data are presented as the mean value \pm standard deviation. The coefficients in the regression equation were determined using the least-squares method. The equation terms were analyzed and statistically verified using F-test with a 95\% confidence level $(p<0.05)$. The photodegradation of amlodipine besylate in the tablets was described using pseudo-first-order kinetics (Equation 3) $\ln \frac{C_{t}}{C_{0}}=-k t$

where are, $C_{t}$ - the concentration of analyte at the irradiation time $t, C_{0}$ - the initial concentration of the analyte, and $k$ - the reaction rate constant.

The half-life $\left(t_{1 / 2}\right)$ of drug photodegradation for the pseudo-first-order kinetics was calculated according to Equation 4.

$t_{1 / 2}=\frac{\ln 2}{k}$

\section{Results and discussion}

In this study, the photostability of amlodipine besylate tablets packed in the Alu/PVC/PVDC blisters was monitored. The primary packaging (PVC/PVDC) is most common in the pharmaceutical industry because it can protect the product from the harmful effects of oxygen, odors, moisture, water vapor, contamination, and bacteria. In this packaging material, PVC was coated with PVDC. Although its volume in the packaging material is small, PVDC plays a crucial role in blister packaging. It reduces the gas and moisture permeability from 5 to 10 times compared to blister packaging made only of PVC. The coated PVC films have a thickness of 0.2032 $0.2540 \mathrm{~mm}$, where the thickness of the PVDC layer was about $0.0254-0.0508 \mathrm{~mm}$.

Optimization of stability-indicating RP-HPLC method

According to the $\mathrm{ICH}$ guidelines, the development and validation of the stability-indicating method are required during the investigation of drug stability. The HPLC method is important in stability studies due to the high resolution, sensitivity, and specificity. In this paper, a modified stability-indicating RP-HPLC method for the determination of amlodipine besylate in the presence of its impurity $D$ was validated. This method was applied for monitoring the photostability of amlodipine besylate in the tablets and the samples after irradiation. The chromatographic conditions were optimized to provide a good performance of the assay. During method optimization, the effects of $\mathrm{C} 18$ and $\mathrm{C} 8$ columns, the portion of acetonitrile in the mobile phase, and $\mathrm{pH}$ value were analyzed. The chromatographic separation was achieved on a ZORBAX Eclipse XDB-C18 column $(4.6 \times 250 \mathrm{~mm}, 5 \mu \mathrm{m})$ and using a mobile phase acetonitrile:methanol:triethyla mine solution (15:35:50, v/v/v). For $\mathrm{pH}$ values below 3.0, the separation of amlodipine besylate and impurity $D$ did not have a satisfactory resolution. The maximum absorption of amlodipine besylate was detected at $273 \mathrm{~nm}$ and it was chosen for further analysis. The retention times of amlodipine besylate and impurity D were 16.529 and $2.575 \mathrm{~min}$, respectively (Figure 1a). The total time of the analysis was less than $10 \mathrm{~min}$. 

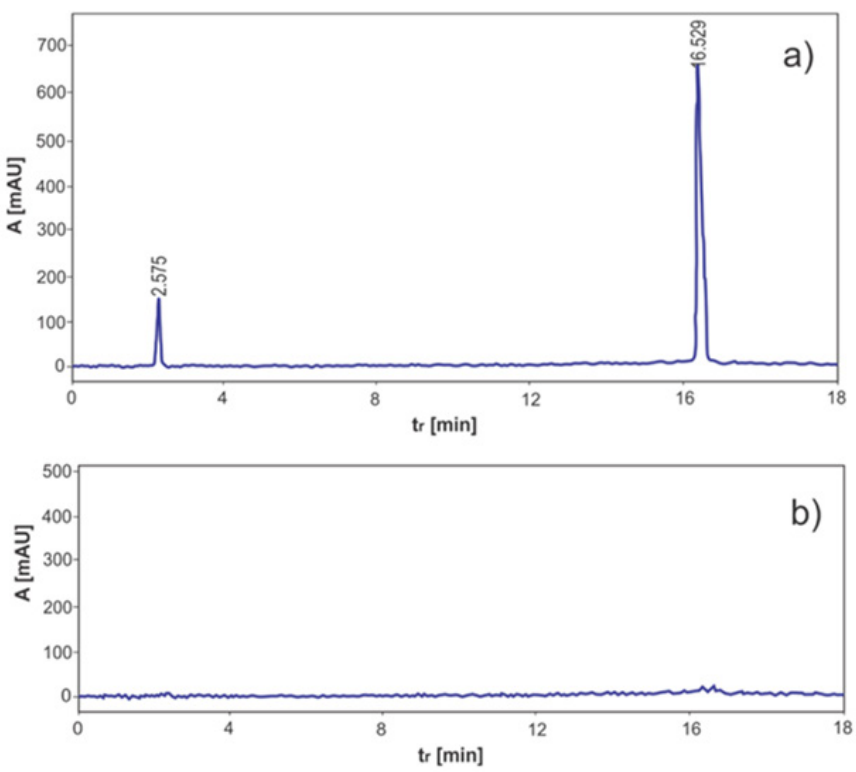

Figure 1. The RP-HPLC chromatogram of: the mixture of amlodipine besylate $\left(t_{r}=16.529 \mathrm{~min}\right)$ and its pharmacopeia impurity $\mathrm{D}\left(t_{r}=2.575 \mathrm{~min}\right)(\mathrm{a})$, and placebo (b)

The chromatographic parameters, such as column efficiency and peak asymmetry were reconsidered for the standard of amlodipine besylate. The height equivalent to a theoretical plate (HETP) of 0.786 was calculated based on the number of theoretical plates $(\mathrm{N})$ of 324. This value indicated a satisfactory column efficiency. The peak asymmetry of 0.44 indicated that the peak was not ideally symmetric, i.e. it is not Gauss's peak. Since $W_{a b}<W_{b c}$, there is a certain interaction between the stationary phase and investigated component.

\section{Method validation}

The primary aim of any laboratory analysis is to be rapid, accurate, and to provide credible results that can be achieved after method validation. Having in mind, the modified stability-indicating RP-HPLC method was validated for the determination of amlodipine besylate in the presence of its impurity $\mathrm{D}$. These compounds were monitored in the tablets treated by UV and Vis radiation.

\section{Selectivity.}

The selectivity was the ability to determine the content of the desired analyte in the presence of other compounds. The chromatogram obtained for the mixture of standards and placebo are depicted in Figures 1a and $1 \mathrm{~b}$, respectively. The peaks of amlodipine besylate and its impurity $D$ were not noticed in the chromatogram of the placebo. It indicated that the excipients did not interfere with chromatographic monitoring of the content of amlodipine besylate and its impurity $D$ in the samples.

Linearity of the method. The method's linearity was confirmed in the concentration range of $10-75 \mathrm{\mu g} \mathrm{mL}^{-1}$. The regression parameters of the calibration curve (slope and intercept) are given in Table 4. The coefficient of determination of 0.999 indicated there is a strong lin- ear relationship between peak area and concentration. The fitting data was also estimated by the calculation of standard error (S.E.) for the slope and intercept of the regression equation with a $95 \%$ confidence interval.

Table 4. Validation parameters of the RP-HPLC method Parameter

Regression

Slope (S.E. $\left.{ }^{a}\right)$

119.525 (1.789)

Intercept (S.E.) ${ }^{a}$

$37.311(1.621)$

Coefficient of determination

0.999

Validation parameters

$\begin{array}{lc}\text { Linearity }\left(\mu \mathrm{g} \mathrm{mL}^{-1}\right) & 10-75 \\ \text { Limit of detection }\left(\mu \mathrm{g} \mathrm{mL}^{-1}\right) & 0.2 \\ \text { Limit of quantification }\left(\mu \mathrm{g} \mathrm{mL}^{-1}\right) & 0.66\end{array}$

aMean standard error

Accuracy of the method. The accuracy of the method was carried out with three different concentrations of amlodipine besylate: 10,20 , and $30 \mu \mathrm{g} \mathrm{mL}^{-1}$ (Table 5). Each sample was analyzed ten times $(n=10)$. The accuracy was estimated based on recovery (\%) which was in the range of $97.63-102.35 \%$.

Table 5. The accuracy of the RP-HPLC method for the determination of amlodipine besylate $(n=10)$

\begin{tabular}{cccc}
\hline \multicolumn{3}{c}{ Level } & \multicolumn{2}{c}{ Concentration $\left(\mu \mathrm{gL}^{-1}\right)$} & Recovery (\%) \\
& Mean value \pm SD & RSD (\%) & \\
\hline $10 \mu \mathrm{g} \mathrm{mL}^{-1}$ & $10.18 \pm 0.13$ & 0.69 & 101.80 \\
$20 \mu \mathrm{g} \mathrm{mL}^{-1}$ & $20.47 \pm 0.43$ & 0.58 & 102.35 \\
$30 \mu \mathrm{g} \mathrm{mL}^{-1}$ & $29.29 \pm 0.44$ & 0.49 & 97.63
\end{tabular}

SD - standard deviation; RSD - relative standard deviation

Table 6. The precision of the RP-HPLC method for the determination of amlodipine besylate $(n=10)$

\begin{tabular}{ccccc}
\hline $\begin{array}{c}\text { Concentration } \\
\left(\mu \mathrm{g} \mathrm{mL}^{-1}\right)\end{array}$ & \multicolumn{3}{c}{ Determined concentration (RSD, \%) } & Reproductivity \\
& day 1 & day 2 & day 3 & $($ RSD, \%) \\
\hline 10 & $9.14(0.61)$ & $10.83(0.59)$ & $10.71(0.76)$ & $8.07(1.23)$ \\
20 & $20.89(0.45)$ & $20.34(0.80)$ & $19.68(0.67)$ & $21.81(1.78)$ \\
30 & $29.49(0.53)$ & $28.86(0.84)$ & $31.07(0.72)$ & $28.59(1.88)$ \\
\hline
\end{tabular}

It can be concluded that the proposed analytical method has high accuracy because the obtained values were deviated by about $3 \%$ from the declared value $(100 \%)$, and the standard deviation was low (SD < 1.0) 
The precision of the method. Repeatability (first level of method's precision) was determined by measuring the same sample ten times $(n=10)$ according to the anaIytical regulation during the same day. Mean precision (second level of method's precision) was checked by consecutive repetition of the same procedure for several days. The solutions of amlodipine besylate were used in the concentration range of $10-30 \mu \mathrm{gL}^{-1}$ (Table 6) for these investigations. Reproducibility (third level of method's precision) was analyzed on another RP-HPLC system. The obtained results are presented as the mean value with a relative standard deviation (RSD).

The RSD values were in the range of $0.45 \%-0.61 \%$ and $0.59 \%-0.84 \%$ for repeatability and mean precision, respectively. These values were lower than $1 \%$, which was predicted theoretically; only in the case of reproducibility of the method the values should be lower than $3 \%$. The obtained results indicated that the proposed method for the determination of amlodipine besylate has a satisfactory precision.

LOD and LOQ. The obtained values of $L O D$ and $L O Q$ were $0.2 \mu \mathrm{g} \mathrm{mL}^{-1}$ and $0.66 \mu \mathrm{g} \mathrm{mL}^{-1}$, respectively (Table 4). The LOD and LOQ represent the lowest content of amlodipine besylate that can be detected or quantified, respectively.

Method robustness. The increase in mobile phase flow rate $\left(0.8,1.0\right.$, and $\left.1.2 \mu \mathrm{g} \mathrm{mL}^{-1}\right)$ leads to the following changes: the number of theoretical plates was 327 , 324 , and 319 , respectively, while the peak asymmetry was $0.41,0.44$, and 0.40 , respectively. The portion of acetonitrile $(10 \%$ and $20 \%)$ in the mobile phase was affected as follows: the number of theoretical plates was 328 and 320 , respectively, while the peak asymmetry was 0.39 and 0.45 , respectively. In all the deliberate varied chromatographic conditions, such as flow rate and proportion of acetonitrile, significant changes in the number of theoretical plates were not noticed. This behavior of the proposed RP-HPLC method is a characteristic of the robust method.

The photodegradation of amlodipine besylate in the presence of its impurity D

In this study, the photodegradation study of amlodipine besylate tablets packed in the Alu/PVC/PVDC blister packaging was carried out after the validation of the proposed method. The content of amlodipine besylate was monitored in the presence of its impurity D. The samples were irradiated by UV and Vis radiation for 15 days. In both chromatograms (Figure 2), amlodipine besylate was confirmed at 16.521 and $16.523 \mathrm{~min}$, i.e. its impurity was detected at $2.571 \mathrm{~min}$ and $2.577 \mathrm{~min}$. The presence of new degradation products was not confirmed by the proposed method. The decrease in the peak area of amlodipine besylate was higher in the case of UV radiation. In this study, a significant change in the peak area of impurity $D$ was not detected. After 14 days of UV and Vis radiation, the content of amlodipine besylate was decreased by $22.38 \%$ and $19.89 \%$, respec- tively. Having in mind that the content of impurity $D$ was lower than the allowed value $(0.1 \%)$, the tablets can be considered safe to use even after their exposure to light during storage and use.
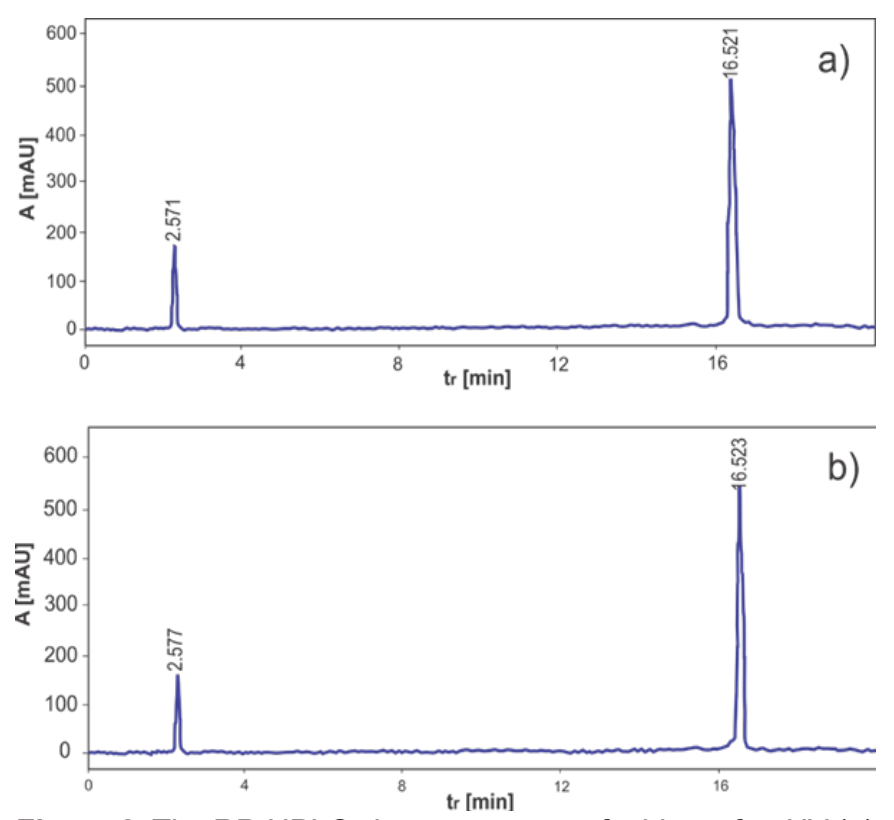

Figure 2. The RP-HPLC chromatograms of tablets after UV (a) and $\mathrm{Vis}(\mathrm{b})$ radiation

The results obtained in this study were different compared with the available results because the experimental conditions (light intensity, irradiation time), the dosage forms (powder, solution, suspension, tablet), or the presence of other active substances were not the same. The stability of amlodipine besylate in the solid-state was monitored in acidic, alkaline, and neutral mediums, under oxidative stress at room temperature, as well as under thermal and photolytic stress conditions $(1.2 \times 106$ lux $\mathrm{h}$ fluorescent light and $200 \mathrm{~W} \mathrm{~h} \mathrm{~m}^{-2}$ UVA light, 14 days) [1]. Amlodipine besylate is unstable in the acidic medium, while stable in all other mediums. Shaalan et al. [11] confirmed that amlodipine besylate was stable in the solid-state after its UV radiation at $254 \mathrm{~nm}$ for $60 \mathrm{~h}$. The photodegradation of amlodipine besylate was also monitored in the various solvents, such as water, methanol, and their mixtures. Mohamed et al. [17] showed that the methanolic solution of amlodipine besylate, directly exposed to daylight for $72 \mathrm{~h}$, was unstable. For this reason, the content of amlodipine besylate was reduced by $34.3 \%$. Kerai et al. [12] concluded that the decrease in methanol concentration led to the reduction of the degradation of amlodipine besylate. They determined that the content of amlodipine besylate was reduced by $7.9 \%$ in $70 \%(\mathrm{v} / \mathrm{v})$ methanol. This result indicates that amlodipine besylate is stable under given photocatalytic conditions (1.2 million lux $\mathrm{h}$ for $24 \mathrm{~h}$ ). Recently, Bhayani et al. [18] reported that the content of amlodipine besylate in an aqueous solution was decreased by $7.86 \%$ after irradiation with 1.2 million lux $\mathrm{h}$ and $200 \mathrm{~W} \mathrm{~h} \mathrm{~m}^{-2}$. Under the same conditions, the degradation of amlodipine besylate 
in the solid-state was $1.09 \%$. Stoiljković et al. [9] concluded that the photodegradation of amlodipine besylate with 1.2 million lux $\mathrm{h}$ and $200 \mathrm{~W} \mathrm{~h} \mathrm{~m}^{-2}$ depended on the irradiation time. They found that the degradation of amlodipine besylate of $32.2 \%$ was due to the irradiation of the solution for 14 days. After the UV radiation (366 nm) of the same sample for $2 \mathrm{~h}$, the degradation of $14.1 \%$ was achieved. Comparing these results with the results obtained in our study, it can be concluded that the excipients and primary packaging play a significant role in the photoprotection of amlodipine besylate. The impact of primary packaging (Alu/Alu blister) was observed on the stability of amlodipine besylate in rapidly disintegrating tablets for 6 months under real $\left(30{ }^{\circ} \mathrm{C}, 65 \%\right.$ of relative humidity) and stress $\left(40{ }^{\circ} \mathrm{C}, 75 \%\right.$ of relative humidity) conditions [19]. In both cases, the decrease in the content of amlodipine besylate was lower than $5 \%$. Therefore, the used primary packaging can be considered adequate for drug storage.

\section{Studies of degradation kinetics}

Based on the previous knowledge of amlodipine besylate photodegradation, the half-life of tablets was determined in this study. Jakimska et al. [20] investigated the photodegradation kinetics of amlodipine besylate in river water during exposure to sunlight and light emitted by a xenon lamp. They found that the photodegradation of amlodipine besylate follows pseudo-first-order kinetics. Table 7 presents the decrease in amlodipine besylate at defined time intervals after UV and Vis photodegradation.

Table 7. The photodegradation of amlodipine besylate expressed as a percentage

\begin{tabular}{lccccc}
\hline Type of radiation & \multicolumn{5}{c}{ Degradation time (day) } \\
& $\mathbf{0}$ & $\mathbf{1}$ & $\mathbf{2}$ & $\mathbf{7}$ & $\mathbf{1 4}$ \\
UV & 0 & 2.48 & 3.91 & 13.02 & 22.38 \\
VIS & 0 & 2.07 & 2.87 & 11.98 & 19.89 \\
\hline
\end{tabular}

The values of reaction rate constant, half-life, and coefficient of determination $\left(R^{2}\right)$ for the photodegradation of amlodipine besylate tablets in the primary packaging after UV and Vis radiation are given in Table 8 . The high values of $\mathrm{R}^{2}$ indicate that the pseudo-first-order kinetics is adequate for describing the photodegradation of amlodipine besylate packed in the primary packaging. A half-life of 38.4 days was noticed for the UV radiation, while the value of 43.3 days was obtained after Vis radiation. This was expected because ultraviolet radiation has shorter waves and higher energy compared to visible radiation. In this way, the satisfactory photostability of amlodipine besylate was achieved in the Alu/PVC/ PVDC blister packaging. Also, the proper selection of excipients is responsible for preserving the drug's stability.
Table 8. Kinetic parameters for pseudo-first-order kinetics of photodegradation of amlodipine besylate in tablets

\begin{tabular}{lcc}
\hline & UV & Vis \\
\hline $\mathbf{k} \times 10^{2}$ (day $\left.{ }^{-1}\right)$ & 1.80 & 1.60 \\
$\mathbf{t}_{1 / 2}$ (day) & 38.4 & 43.3 \\
$\mathbf{R}^{2}$ & 0.998 & 0.994 \\
\hline
\end{tabular}

In the samples exposed to sunlight, the reaction rate constant and half-life of amlodipine besylate photodegradation were 2.66 day $^{-1}$ and 0.3 days, respectively [20]. After the exposure of the same sample to light emitted by a xenon lamp, the reaction rate constant and half-life were 0.08 day $^{-1}$ and $8.8 \mathrm{~min}$, respectively. This behavior is the result of the low stability of amlodipine besylate in river water so that various degradation products can be formed. These products may be harmful to the environment. Zhu et al. [21] also found that the UV photolysis follows the pseudo-first-order kinetics with the reaction rate constant of $0.031 \mathrm{~min}^{-1}$.

\section{Conclusion}

In this paper, the effect of primary packaging (Alu/ PVC/PVDC blister packaging) on the photostability of amlodipine besylate was investigated in the presence of its impurity $D$ in the tablets. The modified stability-indicating RP-HPLC method was validated to monitor the content of amlodipine besylate and its impurity $D$ in the samples obtained after photodegradation. By analyzing the appropriate parameters, it can be concluded that the proposed method is selective, accurate, precise, sensitive, and robust for the simultaneous determination of amlodipine besylate and its impurity. During the photodegradation studies, the content of impurity $D$ was slightly increased $(<0.1 \%)$ and the presence of new degradation products was not noticed. The tablets packed in the used primary packaging can be considered safe for use even after their exposure to light during storage and use.

\section{Acknowledgments}

This work was supported by the Republic of Serbia - Ministry of Education, Science and Technological Development under Program for financing scientific research work, no. 451-03-9/2021-14/200133.

\section{Reference}

[1] R. N. Tiwari, N. Shah, V. Bhalani, A. Mahajan, LC, MS ${ }^{n}$ and LC-MS/MS studies for the characterization of degradation products of amlodipine, Journal of Pharmaceutical Analysis, 5(1) (2015) 33-42.

[2] $\mathrm{ICH}$, Stability Testing: Photostability testing of new drug substances and products Q1B. International Conference on Harmonisation, 2003, 24.

[3] P. Palit, N. Ali, Oral therapy with amlodipine and lacidipine, 
1,4-dihydropyridine derivatives showing activity against experimental visceral leishmaniasis, Antimicrobial Agents and Chemotherapy, 52(1) (2008) 374-377.

[4] The Merck Index, S. Budavari, M. O'Neil, Ann Smith, P. Heckelman, J. Obencha Eds., 12th Edn., Merck Research Lab, Division of Merck and Co. Inc., Whitehouse Station, NY, 1996.

[5] S. C. Sweetman, Martindale: the complete drug reference, 36th Edn., Vol. 3709, Pharmaceutical press, London 2009, p. 1214.

[6] European Pharmacopoeia, $7^{\text {th }}$ Edn., Council of Europe, Strasbourg 2011.

[7] M. S. N. Patel, S. N. Shaikh, M. J. A. Khan, N. I. Deshmukh, M. S. A. Khan, S. J. Khan, A novel derivatization ultraviolet spectrophotometric method for the determination of amlodipine besylate using benzoyl chloride, Journal of Drug Delivery and Therapeutics, 9(6) (2019) 173-178.

[8] M. Sulyma, S. Vasyuk, Y. Zhuk, D. Kaminskyy, O. Chupashko, V. Ogurtsov, New spectrophotometric method of amlodipine besylate determination and its validation, Chemistry and Chemical Technology, 12(4) (2018) 429433.

[9] Z. Ž. Stoiljković, M. Jadranin, S. L. Đurić, S. D. Petrović, M. Avramov Ivić, D. Mijin, Investigation of forced and total degradation products of amlodipine besylate by liquid chromatography and liquid chromatographymass spectrometry, Chemical Industry and Chemical Engineering Quarterly/CICEQ, 20(2) (2014) 295-304.

[10] P. Gibala, M. Douša, A. Kalužíková, M. Tkadlecová, M. Štefko, S. Kalášek, J. Břicháč, Identification and structure elucidation of a new degradation impurity in the multicomponent tablets of amlodipine besylate, Journal of Pharmaceutical and Biomedical Analysis, 162 (2019) 112-116.

[11] R. A. Shaalan, T. S. Belal, F. A. El Yazbi, S. M. Elonsy, Validated stability-indicating HPLC-DAD method of analysis for the antihypertensive triple mixture of amlodipine besylate, valsartan and hydrochlorothiazide in their tablets, Arabian Journal of Chemistry, 10 (2017) S1381-S1394.

[12] J. R. Kerai, A. J. Vyas, B. Vihol, P. Patel, A. Patel, DAD based stability indicating RP-UPLC method for simultaneous determination of olmesartan medoxomil and amlodipine besylate, Pharmaceutical Chemistry Journal, 52(11) (2019) 959-964.

[13] T. B. Deshmukh, S. S. Deo, F. S. Inam, T. L. Lambat, Development and validation of novel HPTLC method for the simultaneous estimation of amlodipine besylate and telmisartan in tablet dosage form using ICH Q2 (R1) directions, Journal of the Chinese Advanced Materials Society, 6(4) (2018) 329-340.

[14] B. P. Marolia, K. B. Bodiwala, S. A. Shah, P. B. Prajapati, B. H. Satani, S. A. Desai, Development and validation of HPTLC method for simultaneous estimation of amlodipine besylate, hydrochlorothiazide and telmisartan in their combined tablet dosage form, Pharmaceutical Methods, 7(1) (2016) 48-53.

[15] The European Medicines Agency Pre-Authorisation Evaluation of Medicines for Human Use. ICH Q2(R1): Validation of Analytical Procedures: Text and Methodology, EMEA/410412/2007, London 2009.

[16] J. Ermer, Validation in pharmaceutical analysis. Part I: An integrated approach, Journal of Pharmaceutical and Biomedical Analysis, 24(5-6) (2001) 755-767.
[17] A. M. I. Mohamed, M. A. Omar, M. A. Hammad, A. A. Mohamed, Development and validation of highly sensitive stability indicating spectrofluorimetric method for determination of amlodipine in pharmaceutical preparations and human plasma, Journal of Fluorescence, 26(6) (2016) 2141-2149.

[18] D. Bhayani, H. Naik, T. N. Nathaniel, S. Khan, P. Mehta, Simulated space radiation: Investigating ionizing radiation effects on the stability of amlodipine besylate API and tablets, European Journal of Pharmaceutical Sciences, 137 (2019) 104982.

[19] S. F. Ahsan, M. A. Sheraz, M. F. Khan, Z. Anwar, S. Ahmed, I. Ahmad, Formulation and stability studies of fast disintegrating tablets of amlodipine besylate, Indian Journal of Pharmaceutical Education and Research, 53(3) (2019) 480-493.

[20] A. Jakimska, M. Śliwka-Kaszyńska, P. Nagorski, J. Namieśnik, A. Kot-Wasik, Phototransformation of amlodipine: degradation kinetics and identification of its photoproducts, PloS One, 9(10) (2014) 1-10.

[21] B. Zhu, B. Zonja, O. Gonzalez, C. Sans, S. Pérez, D. Barceló, S. Esplugas, K. Xu, Z. Qiang, Degradation kinetics and pathways of three calcium channel blockers under UV irradiation, Water Research, 86 (2015) 9-16. 
Izvod

\section{STUDIJA FOTOSTABILNOSTI TABLETA AMLODIPIN BESILATA UPAKOVANIH U PRIMARNOJ AMBALAŽI}

Ivana M. Savic Gajic ${ }^{1}$, Ivan M. Savic ${ }^{1}$, Predrag S. Sibinovic ${ }^{2}$, Valentina D. Marinkovic ${ }^{3}$

${ }^{1}$ Tehnološki fakultet u Leskovcu, Univerzitet u Nišu, Bulevar oslobodjenja 124, 16000 Leskovac, Srbija,

2Farmaceutska i hemijska industrija - Zdravlje Aktavis, Vlajkova 199, 16000 Leskovac, Srbija

${ }^{3}$ Farmaceutski fakultet, Univerzitet u Beogradu, Vojvode Stepe 450, 11221 Beograd, Srbija.

U radu je validirana modifikovana stability-indicating RP-HPLC metoda za kvantitativnu analizu amlodipin besilata u prisustvu njegove nečistoće D (3-etil 5-metil 2-[(2-aminoetoksi)metil]-4-(2-hlorofenil)-6-metilpiridin-3,5-dikarboksilat). Metoda je primenjena za određivanje analita u tabletama i ozračenim uzrocima upakovanih u primarnoj ambalaži (Alu/PVC/PVDC blister pakovanje). Efikasno hromatografsko razdvajanje postignuto je upotrebom ZORBAX Eclipse XDB-C18 kolone $(4,6 \times 250 \mathrm{~mm}, 5 \mu \mathrm{m})$ sa izokratskim eluiranjem mobilne faze koja se sastojala od acetonitrila:metanola:rastvora trietilamina (15:35:50, v/v/v) $(\mathrm{pH} \mathrm{3,0)}$. Protok mobilne faze bio je $1 \mathrm{~mL} \mathrm{~min}{ }^{-1}$, dok je detekcija amlodipin besilata vršena na $273 \mathrm{~nm}$. Amlodipin besilat i nečistoća D su identifikovani pri retencionim vremenima 16,529 min i 2,575 min, respektivno. Linearnost metode sa koeficijentom determinacije 0,999 potvrđena je u opsegu koncentracija 10 - $75 \mu \mathrm{g} \mathrm{mL}^{-1}$ za amlodipin besilat. Granica detekcije bila je $0,2 \mu \mathrm{g} \mathrm{mL}{ }^{-1}$, dok je granica kvantifikacije bila $0,66 \mu \mathrm{g} \mathrm{mL}^{-1}$. Nakon UV i Vis zračenja tableta upakovanih u primarnoj ambalaži, sadržaj amlodipin besilata smanjio se za $22,38 \%$ i $19,89 \%$, respektivno. Prisustvo novih degradacionih proizvoda nije detektovano pri datim hromatografskim uslovima. Fotodegradacija amlodipin besilata sledila je kinetiku pseudo-prvog reda. Na osnovu vrednosti poluvremena degradacije (38,4 dana za UV zračenje i 43,3 dana za Vis zračenje) zaključeno je da je amlodipin besilat u tabletama ima zadovoljavajuću fotostabilnost nakon njegovog pakovanja u Alu/PVC/PVDC blister pakovanju.
(ORIGINALNI NAUČNI RAD) UDK 615.22:544.14:543.54 DOI 10.5937/savteh2101020S

Ključne reči: lek, fotodegradacija, kinetika, RP-HPLC, primarno pakovanje 